BEduManageRs Journal

Borneo Educational Management and Research Journal, Vol.2, No.1, 2021

ISSN: 2747-0504

\title{
Strategi Pembelajaran Karakter Anak Usia Dini model Daring di masa Pandemic Covid-19 (Studi kasus pada PAUD Anak Kita Preschool Samarinda)
}

\author{
Heppy Liana ${ }^{1,2}$ \\ ${ }^{1}$ Managemen Pendidikan Program Doktor Universitas Mulawarman \\ ${ }^{2}$ Fakultas Ilmu Sosial dan Pendidikan Universitas Nahdlatul Ulama Kaltim \\ e-mail: heppy.liana@gmail.com, heppy.liana@unukaltim.ac.id
}

\begin{abstract}
This study aims to describe how the strategy of early childhood educators in carrying out early childhood character learning during the coronavirus19 disease 19 when learning activities are carried out at home. The researcher used a qualitative descriptive approach with a case study method to gain an understanding of the strategies of early childhood educators in implementing early childhood character learning. Data collection techniques used are interviews and documentation. The data collected was then analyzed using an interactive model with data analysis steps, namely data reduction, data presentation, conclusion drawing, and verification. The results showed that there were changes in learning activities carried out before and during the covid-19 pandemic, First: the strategy of implementing learning through collaboration between educators and parents by sharing tasks, namely, educators as planners and assessment of learning outcomes while for the task of implementing learning carried out by parents, so that parents become partners during learning activities at home, including the task of parents is to prepare tools and play materials that are lent by the school and added to the tools and playing materials that are around the house, accompanying children, motivating children and documenting activities that children do then send the documentation to the homeroom teacher to be analyzed and reported as a child development report carried out PAUD educators are assisted by parents at home, secondly: Educator's Strategy in instilling character values through learning activities from At home during the COVID-19 pandemic, there are 12 character values that can be developed in Anak Kita Preschool, including: 1) Religious, 2) Honest, 3) Tolerance, 4) Discipline, 5) Hard work, 6) creative, 7) independent, 8) curious, 9) friendly/communicative, 10) likes to read, 11) cares about the environment, and 12) is responsible. These eleven characters values are developed through stimulation, storytelling, facilitation and good habituation from adults, namely educators and parents and are evaluated based on six aspects of child development.
\end{abstract}

Keywords: learning strategies, collaboration between parents and educators, corona virus-19 pandemic, learning from home, character, early childhood education

\section{PENDAHULUAN}

Saat ini kita berada dalam kondisi yang tidak normal, kehidupan dan lingkungan sekitar kita sedang terganggu dengan hadirnya coronavirus disease atau covid-19 yang telah mengguncang seluruh dunia, Pandemi Covid 19 ini membuat pemerintah membuat kebijakan pembatasan kegiatan di ruang publik, termasuk kegiatan pembelajaran. Sehingga mengeluarkan surat edaran untuk bekerja dari rumah dan belajar dirumah hingga batas waktu yang tidak ditentukan, Kebijakan pemerintah ini tertuang dalam Surat Edaran Menteri Pendidikan dan Kebudayaan Nomor 4 tahun 2020 tentang Pelaksanaan Kebijakan Pendidikan dalam Masa darurat Penyebaran Coronavirus Disease (covid-2019). Hal ini dilakukan untuk memutus mata rantai penyebaran virus covid - 19 semakin meluas di

Jurnal BeduManagers, Vol.2, No.1, Juni 2021 
BEduManageRs Journal

Borneo Educational Management and Research Journal, Vol.2, No.1, 2021

ISSN: 2747-0504

penjuru nusantara Indonesia, Pandemic Covid-19 ini menyebabkan semua sekolah tutup. seluruh kegiatan pembelajaran dilakukan di rumah. Kegiatan Belajar Dari Rumah (BDR) dianggap cukup aman. Penerapan BDR tentunya juga bukan hal yang mudah dan menyenangkan baik bagi pendidik sebagai pendidik, anak sebagai peserta didik, dan orangtua sebagai pendamping anak.

Sehingga diperlukan etos kerja positif, komunikasi, dan kerjasama antara pendidik dan orangtua yang terlibat dalam pembelajaran . kemudian menjadi penting dalam menyikapi pembelajaran di masa pandemi ini, khususnya bagi pendidik PAUD. Hal ini agar pembelajaran dapat berjalan maksimal dan tentunya tetap menyenangkan bagi anak dan orangtua di tengah situasi yang serba terbatas.

Dalam proses belajar mengajar pada dunia Pendidikan, ini merupakan tantangan yang sangat memerlukan kerjasama yang baik antara orangtua dan pendidik, karena kegiatan belajar mengajar sangat lekat dengan interaksi yang melibatkan banyak orang pendidik dengan peserta didik dalam satu lingkungan belajar secara langsung bertatap muka.

Namun karena pandemi covid-19 interaksi secara langsung dihentikan (social distancing) dan diganti dengan aktivitas Pembelajaran Jarak Jauh (PJJ) baik dalam jaringan (daring) maupun luar jaringan (luring), Pembelajaran dalam jaringan (daring) dilaksanakan dengan memanfaatkan media internet sedangkan pembelajaran luring dilakukan dengan cara bertatap muka . Hal ini berlaku untuk seluruh jenjang pendidikan mulai dari pendidikan tinggi, pendidikan menengah, sekolah dasar maupun untuk pendidikan anak usia dini. Satuan-satuan PAUD yang bekerja keras dalam melakukan stimulasi perkembangan anak usia dini melalui kegiatan bermain sambil belajar di ruang-ruang kelas, karena adanya covid-19 diganti dengan belajar di rumah yang disebut dengan Belajar Dari Rumah ( BDR) Kita ketahui bersama bahwa Pendidikan anak usia dini sebagai jenjang pendidikan pra dasar atau sebelum pendidikan dasar memberikan layanan pada anak sejak lahir hingga usia enam tahun dengan memberikan stimulasi berupa pemberian rangsangan pendidikan supaya menunjang pertumbuhan dan perkembangan jasmani serta rohani anak sehingga memiliki keterampilan untuk melanjutkan pada jenjang pendidikan lebih lanjut yaitu sekolah dasar (Permendikbud, Pasal 12014 ).

Hurlock mengatakan bahwa pada masa awal kanak-kanak dikenal dengan sebutan tahap mainan karena semua rutinitas bermain yang mainkan oleh anak usia dini menggunakan mainan (Hurlock, 1980) Selanjutnya dikemukakan oleh Papalia dan Feldman bahwa bermain sebagai kegiatan dan aktivitas anak usia dini memiliki andil terhadap aspek-aspek perkembangan anak usia dini. Melalui aktivitas bermain anak menguasai fungsi-fungsi tubuh dengan baik, mengkoordinasi antara mata dengan gerakannya, melatih otot-otot anak, membuat keputusan dan mendapatkan keahlian/kemampuan baru (Papalia \& Feldman, 2015).

Pola pembelajaran anak usia dini di satuansatuan PAUD yang sebelumnya dilakukan dengan pelibatan aktif dari pendidik dan anak melalui kegiatan bermain sambil belajar karena adanya coronavirus disease atau covid-19, semua aktivitas pembelajaran dilaksanakan di rumah. Pemberian stimulasi perkembangan untuk 6 aspek perkembangan anak yang terdiri dari kognitif, bahasa, fisik motorik, sosial emosional, agama dan moral serta seni harus dilakukan di rumah masingmasing anak dengan didampingi orangtua karena saat bermain anak dilibatkan untuk bereksplorasi, mendeteksi dan menggunakan media berupa bahan/ alat main yang dipinjamkan dari sekolah dan juga bahan main ada di sekitar rumah .

Jurnal BeduManagers, Vol.2, No.1, Juni 2021 
BEduManageRs Journal

Borneo Educational Management and Research Journal, Vol.2, No.1, 2021

ISSN: 2747-0504

Dalam Masa Pandemi Covid- 19, Stimulasi pendidikan karakter tidak boleh berhenti karena ini merupakan salah satu yang wajib diajarkan sejak usia dini melalui pembiasaan - pembiasaan yang dilakukan sehari -hari dan orang dewasalah yang akan menjadi contoh untuk anak, hal ini tentunya menjadi tugas berat orang tua dan pendidik, karena karakter seseorang dibentuk oleh lingkungan terdekat anak diantaranya pendidikan dirumah, di sekolah dan di lingkungan masyarakat. Ketiga pilar tersebut sangat erat kaitannya, sehingga harus saling mendukung.

Pada Undang-undang nomor 20 tahun 2003 tentang Sistem Pendidikan Nasional pasal 3 dikatakan bahwa Pendidikan nasional bertujuan untuk berkembangnya potensi peserta didik agar menjadi manusia yang beriman bertaqwa kepada Tuhan YME, berakhlak mulia, sehat, berilmu, cakap, kreatif, mandiri, dan menjadi warga negara yang demokratis serta bertanggung jawab. karena itu pendidikan karakter perlu dilakukan karena ini sesuai dengan semangat pendidikan nasional.

Sekolah sebagai satuan pendidikan yang bertugas mewujudkan tujuan Pendidikan Nasional, dalam rangka mengembangkan potensi peserta didik agar menjadi manusia yang beriman dan bertaqwa kepada Tuhan Yang Maha Esa, Berakhlak mulia, sehat, berilmu, cakap, Kreatif, mandiri, dan menjadi warga negara yang demokratis serta bertanggung jawab. Maka peranan pendidik disekolah menjadi sangat penting dalam kaitannya pembentukan Karakter anak bangsa Dalam mewujudkan generasi yang bermutu yang memiliki karakter saat ini sangat dibutuhkan mengingat akhir-akhir ini terlihat secara nyata bahwa pendidikan telah gagal membimbing, membentuk generasi yang berkarakter, dan tujuan pengembangan karakter pada anak usia dini adalah mendorong lahirnya anak-anak yang berkarakter baik. Dengan pendidikan karakter, seorang anak akan menjadi cerdas emosinya. Kecerdasan emosi adalah bekal terpenting dalam mempersiapkan anak menyongsong masa depan, karena dengannya seseorang akan dapat berhasil dalam menghadapi segala macam tantangan, termasuk tantangan untuk berhasil secara akademis Character isnt inherited. One builds its daily by the way one thinks and act, thought, action by action (Helen G. Douglas ) Karakter tidak diwariskan, tetapi sesuatu yang dibangun secara berkesinambungan hari demi hari melalui pikiran dan perbuatan, pikiran demi pikiran, tindakan demi tindakan.

Berdasarkan pendapat Douglas tersebut di atas, maka sudah sangat tepat apabila peran lembaga PAUD menjadi wadah pembentukan karakter anak usia dini secara terus menerus melalui praktek yang baik dan kegiatan-kegiatan yang tepat dari hari kehari yang sudah terencana dan terselengara dengan baik oleh pendidik di lembaga PAUD. Dengan kata lain, anak-anak yang telah melalui pembelajaran karakter pada lembaga PAUD mempunyai kemampuan yang lebih tinggi dari pada anak-anak yang tidak mengenyam pendidikan anak usia dini terutama dalam kemampuan akademik, kreativitas, inisiatif, motivasi dan kemampuan sosialnya. Berbeda dengan anak usia 6 tahun yang langsung dimasukkan ke Sekolah Dasar, kondisi psikologis mereka belum siap sehingga merasa tidak mampu dan rendah diri. Ini sangat berbahaya karena bisa mematikan semangat dan kecintaan mereka untuk belajar, apalagi kalau di lingkungan anak usia dini tidak mendapatkan pola pengasuhan yang tepat dalam pembentukan karakter mereka di usia atau periode kritis mereka. Informasi tersebut menunjukkan betapa pentingnya lembaga PAUD dan pola pengasuhan itu perlu diterapkan di masa emas anak usia dini dalam memberikan pendidikan karakter yang baik dan tepat, karena masa ini sangat menentukan kesuksesan anak di masa depan. Didukung oleh pernyataan Michele Borba dalam bukunya The Big Book of Parenting

Jurnal BeduManagers, Vol.2, No.1, Juni 2021 
BEduManageRs Journal

Borneo Educational Management and Research Journal, Vol.2, No.1, 2021

ISSN: 2747-0504

Solution, 2009, bahwa pengasuhan adalah amanah bagi orang tua sepanjang hidupnya, hal ini dikarenakan pengasuhan dilakukan tanpa henti dari sejak anak dalam kendungan, usia dini, remaja hingga dewasa dapat membentuk watak dan karakter mereka dalam menjalani penghidupannya.

\section{METODE PENELITIAN}

Fokus penelitian ini berkaitan dengan aktivitas anak, orang tua dan pendidik, dalam melaksanakan pembelajaran nilai-nilai karakter anak usia dini saat Belajar Dari Rumah ( BDR ) yang dilaksanakan saat pandemic covid-19. Oleh karena itu pendekatan yang digunakan adalah kualitatif deskriptif. Pengumpulan data meliputi (1) Observasi, (2) Wawancara mendalam, (3) Catatan lapangan, (4) Dokumentasi. Teknik analisa data yang digunakan adalah model analisis interaktif yang dikembangkan oleh Miles dan Huberman, yaitu reduksi data, display data, dan penarikan kesimpulan/verifikasi.

Dalam penelitian ini digunakan teknik pemeriksaan data melalui teknik triangulasi. Teknik ini dimaksudkan untuk memperoleh derajat kepercayaan yang tinggi. Triangulasi sebagai teknik pemeriksaan keabsahan data yang memanfaatkan sesuatu yang lain di luar data untuk keperluan pengeceken atau pembanding terhadap data yang dipakai dalam proses menemukan kesimpulan dengan pengumpulan data yang berbeda-beda dari sumber yang sama dari berbagai sudut pandang.

\section{HASIL DAN PEMBAHASAN}

Implementasi pembelajaran karakter yang dilaksanakan di sekolah sebagai salah satu aspek perkembangan yang akan dinilai dilaksanakan oleh orang tua saat belajar dari rumah di PAUD Anak kita Preschool Samarinda selaku satuan pendidikan anak usia dini yang memberikan layanan untuk anak usia yang berusia satu sampai enam tahun secara intens dan sistematis memberikan stimulasi perkembangan anak usia dini pada aspek-aspek yang telah ditentukan oleh standar nasional pendidikan anak usia dini terdiri dari aspek kognitif, fisik motorik, sosial emosional, bahasa, agama dan moral serta seni.

Pemberian stimulasi perkembangan kognitif pada anak usia dini di PAUD Anak Kita Preschool Samarinda dilakukan dengan berpedoman pada indikator capaian perkembangan yang ada dalam Permendikbud nomor 137 tahun 2014 tentang standar nasional pendidikan anak usia dini. Perkembangan kognitif dalam standar PAUD diberikan lingkup perkembangan antara lain belajar dan pemecahan masalah, berfikir logis dan berfikir simbolik dengan indikator capaian masing-masing perkembangan yang berbeda. Diharapkan, ransangan atau stimulasi yang diberikan kepada semua aspek perkembangan anak usia dini sudah sesuai dengan indikator capaian perkembangannya yang tercantum dalam STPPA, sehingga proses pembentukan karakter mereka dapat terwujud sesuai dengan pembelajaran yang diharapkan.

Penelitian dilakukan di PAUD Anak Kita Preschool Samarinda yang merupakan satuan Pendidikan Anak Usia Dini Terakreditasi A dari Badan Akreditasi Nasional PAUD dan PNF yang memberikan layanan usia nak 1-6 tahun yang beralamat di Jalan Jakarta Blok AC No 16 Samarinda.

Adapun waktu pelaksanaan penelitian yaitu pada bulan maret hingga Juni 2020 atau sejak diberlakukannya larangan untuk berkumpul (social distancing) karena adanya pandemic covid19, dimana seluruh pelaksanaan pembelajaran pada seluruh jenjang pendidikan dihimbau untuk dilakukan dari rumah. subjek penelitian ditentukan oleh peneliti yaitu anak PAUD Anak kita Preschool yang diberikan stimulasi perkembangan oleh orang tuanya di rumah kemudian di dampingi dan dilaporkan hasil pelaksanaannya melalui

Jurnal BeduManagers, Vol.2, No.1, Juni 2021 
BEduManageRs Journal

Borneo Educational Management and Research Journal, Vol.2, No.1, 2021

ISSN: 2747-0504

media sosial whatsapp Grup Sekolah dan Google Form yang disiapkan oleh pendidik.

Selanjutnya, wawancara dan dokumentasi adalah teknik utama untuk mengumpulkan data dalam penelitian. Alasan penggunaan teknik wawancara dan dokumentasi dalam penelitian yaitu adanya larangan untuk melakukan interaksi secara dekat dengan orang lain social dan physical distancing yang tidak memungkin peneliti menggunakan teknik pengumpulan data lainnya secara tatap muka. Data yang terkumpul selanjutnya dianalisis dengan menggunakan langkah-langkah yaitu reduksi data, penyajian data, penarikan kesimpulan dan verifikasi.

\section{PENANAMAN NILAI-NILAI KARAKTER SAAT BDR}

- Dalam kondisi pandemi covid19 ini, proses pemberian stimulasi pendidikan karakter tetap dilaksanakan melalui Pembelajaran Jarak Jauh atau Belajar Dari Rumah (BDR) yang dilakukan dengan menggunakan rencana pembelajaran yang dibuat oleh pendidik dan disampaikan kepada orang tua agar orang tua dapat memfasilitasi kegiatan yang akan dilakukan bersama anak, baik itu menyiapkan alat dan bahan main, memotivasi anak, mendampingi anak dan mendokumentasikan kegiatan yang anak lakukan, maupun mengevaluasi hasil dokumentasi baik foto ataupun video serta hasil karya itu dikirimkan kepada pendidik untuk selanjutnya dilakukan analisa perkembangan anak oleh pendidik dan dilaporkan sebagai hasil perkembangan anak kepada orang tua. Selanjutnya, pada kegiatan belajar dari rumah, nilai-nilai karakter yang dikembangkan oleh pendidik di PAUD Anak Kita Preschool ada 12 nilai karakter, antara lain: 1) Religius, 2) Jujur 3) toleransi, 4) disiplin , 5) kerja keras, 6) kreatif, 7) mandiri, 8) rasa ingin tahu, 9) bersahabat/ komunikatif,
10) gemar membaca,11) peduli lingkungan dan 12) bertanggung Jawab

Sedangkan kegiatan penanaman nilai karakter di saat pembelajaran dilakukan di rumah pada masa Pandemi Covid-19 ini dapat terlihat dari dokumentasi yang dikirimkan orang tua kepada pendidik di sekolah, nilai karakter tersebut dapat dilihat dari dokumentasi berupa foto, video dan dan hasil karya anak yang dikirimkan orang tua kepada pendidik diantaranya :

\begin{tabular}{|c|c|c|}
\hline No & $\begin{array}{l}\text { Nilai } \\
\text { Karakter }\end{array}$ & $\begin{array}{l}\text { Aktivitas Penanaman } \\
\text { Nilai Karakter }\end{array}$ \\
\hline 1 & Religius & 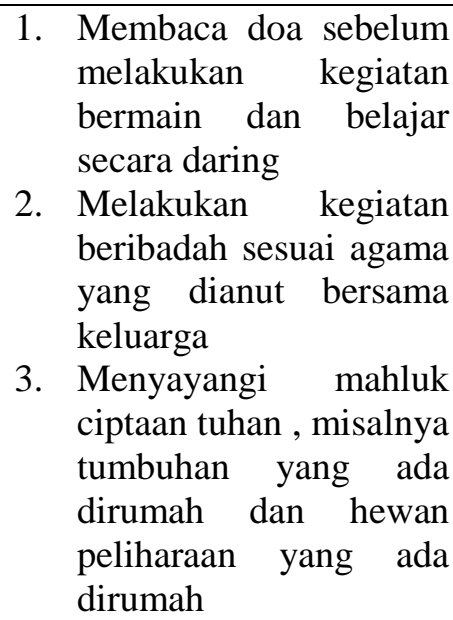 \\
\hline 2 & Jujur & $\begin{array}{l}\text { 1. Jujur dalam berkata } \\
\text { 2. Jujur dalam menjawab } \\
\text { pertanyaan yang } \\
\text { diajukan pendidik saat } \\
\text { bermain dan belajar } \\
\text { daring }\end{array}$ \\
\hline 3 & Toleransi & $\begin{array}{l}\text { 1. Toleransi antar teman } \\
\text { dan anggota keluarga } \\
\text { 2. Berempati ketika ada } \\
\text { teman yang sakit } \\
\text { berduka } \\
\text { 3. Menginformasikan hari } \\
\text { libur keagamaan yang } \\
\text { yang membuat hari } \\
\text { kegiatan pembelajaran } \\
\text { daring juga libur }\end{array}$ \\
\hline 4 & Disiplin & $\begin{array}{ll}\text { 1. } & \begin{array}{l}\text { Disiplin } \\
\text { melakukan }\end{array} \\
\text { kegiatan }\end{array}$ \\
\hline
\end{tabular}

Jurnal BeduManagers, Vol.2, No.1, Juni 2021 
BEduManageRs Journal

Borneo Educational Management and Research Journal, Vol.2, No.1, 2021

ISSN: 2747-0504

\begin{tabular}{|c|c|c|}
\hline & & $\begin{array}{l}\text { sesuai arahan pendidik, } \\
\text { 2. Hadir tepat waktu } \\
\text { sesuai jadwal kelas saat } \\
\text { berkegiatan belajar } \\
\text { daring melalui aplikasi } \\
\text { video conference zoom } \\
\text { meeting yang } \\
\text { dilaksanakan rutin oleh } \\
\text { PAUD Anak Kita } \\
\text { Preschool }\end{array}$ \\
\hline 5 & Kerja keras & $\begin{array}{l}\text { 1. Dapat menyelesaikan } \\
\text { kegiatan bermainnya } \\
\text { hingga tuntas saat } \\
\text { kegiatan bermain dan } \\
\text { belajar secara daring } \\
\text { melalui Zoom Meeting } \\
\text { 2. Dapat dengan fokus } \\
\text { mendengarkan cerita } \\
\text { yang disampaikan } \\
\text { pendidik saat awal } \\
\text { pembelajaran daring } \\
\text { 3. Bersungguh- sungguh } \\
\text { Ketika mengerjakan } \\
\text { proyek individu }\end{array}$ \\
\hline 6 & Kreatif & $\begin{array}{l}\text { 1. Kreatif dalam } \\
\text { menciptakan hasil karya } \\
\text { dengan menggunakan } \\
\text { bahan dan alat main } \\
\text { yang dipinjamkan dari } \\
\text { sekolah dan bahan dan } \\
\text { alat main ada disekitar } \\
\text { rumah } \\
\text { 2. Menggunakan alat dan } \\
\text { bahan main dari } \\
\text { lingkungan sekitar } \\
\text { rumah batu-batuan, } \\
\text { tumbuhan, daun-daun } \\
\text { kering, ranting katu dllB } \\
\text { 3. Membuat hasil karya } \\
\text { dengan hasil baru }\end{array}$ \\
\hline 7 & Mandiri & $\begin{array}{l}\text { 1. Mandiri dalam } \\
\text { mengerjakan kegiatan } \\
\text { yang dilakukan } \\
\text { 2. Menyelesaikan kegiatan } \\
\text { hingga tuntas secara } \\
\text { mandiri }\end{array}$ \\
\hline
\end{tabular}

\begin{tabular}{|c|c|c|}
\hline & & $\begin{array}{l}\text { 3. Tidak tergantung orang } \\
\text { dewasa } \\
\text { mengerjakan proyek } \\
\text { individu }\end{array}$ \\
\hline 8 & $\begin{array}{l}\text { Rasa ingin } \\
\text { tahu }\end{array}$ & $\begin{array}{l}\text { 1. Bertanya jika ada yang } \\
\text { belum dipahami ketika } \\
\text { sedang belajar daring, } \\
\text { stimulasi yang } \\
\text { dilakukan pendidik } \\
\text { misalnya dengan berkata } \\
\text { : Baik... teman-teman, } \\
\text { apakah yang bunda } \\
\text { sampaikan sudah } \\
\text { dipahami atau ada yang } \\
\text { ingin bertanya,? } \\
\text { 2. Ingin mengetahui secara } \\
\text { dalam dan lebih luas apa } \\
\text { yang disampaikan } \\
\text { pendidik saat kegiatan } \\
\text { daring } \\
\text { 3. Melihat dan menyimak } \\
\text { yang disampaikan oleh } \\
\text { pendidik saat kegiatan } \\
\text { daring }\end{array}$ \\
\hline 9 & $\begin{array}{l}\text { Bersahabat/ } \\
\text { Komunikatif }\end{array}$ & 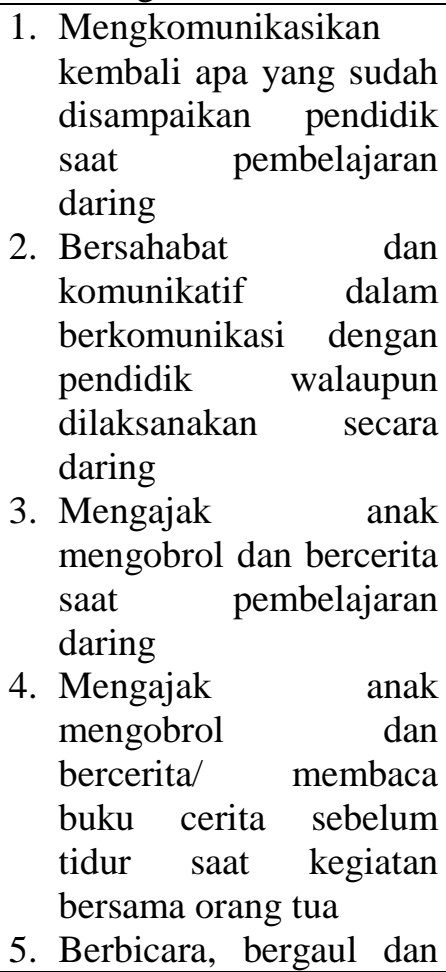 \\
\hline
\end{tabular}


BEduManageRs Journal

Borneo Educational Management and Research Journal, Vol.2, No.1, 2021

ISSN: 2747-0504

\begin{tabular}{|c|c|c|}
\hline & & $\begin{array}{l}\text { bekerjasama saat } \\
\text { pembelajaran daring }\end{array}$ \\
\hline 10 & $\begin{array}{l}\text { Gemar } \\
\text { membaca }\end{array}$ & $\begin{array}{l}\text { 1. Membaca buku cerita } \\
\text { dan simbol yang ada } \\
\text { disekitar rumah dan } \\
\text { lingkungan terdekatnya } \\
\text { 2. Mengajak an ak } \\
\text { membaca buku yang } \\
\text { diinginkan } \\
\text { 3. Orang tua / pendidik } \\
\text { menyediakan waktu } \\
\text { untuk membacakan anak } \\
\text { buku cerita }\end{array}$ \\
\hline 11 & $\begin{array}{l}\text { Peduli } \\
\text { lingkungan }\end{array}$ & $\begin{array}{l}\text { 1. Menggunakan benda } \\
\text { disekitar lingkungan } \\
\text { rumah sebagai media } \\
\text { pembelajaran, misalnya } \\
\text { tanaman dan binatang } \\
\text { kegiatan yang diberikan } \\
\text { adalah kegiatan } \\
\text { menyiram tanaman dan } \\
\text { menyayangi hewan } \\
\text { peliharaa yang ada } \\
\text { dirumah misal anak } \\
\text { memiliki kucing ikan, } \\
\text { hamster, marmut, } \\
\text { kelinci } \\
\text { 2. Menjaga alat dan bahan } \\
\text { main sehingga tidak } \\
\text { rusak } \\
\text { 3. Membersihkan } \\
\text { lingkungan setelah } \\
\text { bermain }\end{array}$ \\
\hline 12 & $\begin{array}{l}\text { Bertanggung } \\
\text { jawab }\end{array}$ & 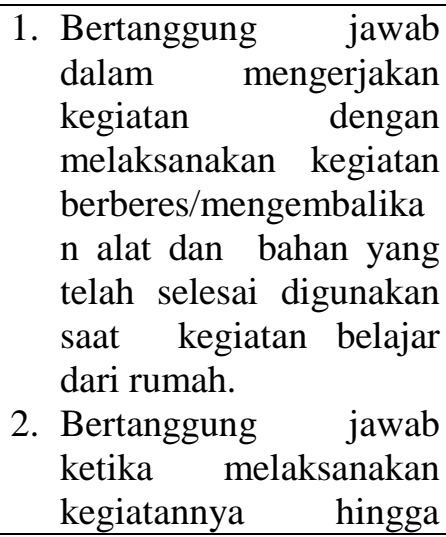 \\
\hline
\end{tabular}

\begin{tabular}{|l|l|}
\hline & tuntas \\
\hline
\end{tabular}

Semua kegiatan penanaman nilai karakter anak usia dini saat belajar dari rumah dimasa Pandemi covid-19 ini dilakukan dengan pemberian stimulasi terhadap perkembangan anak usia dini dilakukan secara efektif dan efisien oleh pendidik PAUD dengan memfasilitasi beragam media sebagai sarana pembelajaran dengan prinsip bahwa aktivitas utama anak bermain sambil belajar.

Dukungan orangtua juga memberikan pengaruh yang besar untuk membantu meningkatkan stimulasi penanaman nilai-nilai karakter anak usia dini saat pembelajaran dilaksanakan dirumah sehingga diperlukan komunikasi efektif antara orang tua dan pendidik agar pembelajaran berjalan lancar. Dan tidak dipungkiri komunikasi memegang peranan penting dalam keberhasilan stimulasi penanaman nilai nilai karakter di rumah keluarga yang dilandasi praktik baik pengasuhan agar dapat terinternalisasikan dalam diri anak. Pelibatan keluarga pada satuan Pendidikan akan meningkatkan komunikasi yang efektif antara pendidik PAUD dan Orang tua yang dilakukan melalui kegiatan parenting class yang dilakukan secara daring ( dalam jaringan ) melalui aplikasi zoom meeting PAUD Anak Kita Preschool Pendidik anak usia dini menurut peraturan menteri pendidikan dan kebudayaan nomor 137 tentang standar nasional pendidikan anak usia dini terdiri atas pendidik PAUD, pendidik pendamping dan pendidik pendamping muda yang penentuan statusnya apakah pendidik utama atau pendidik pendamping didasarkan pada kualifikasi pendidikan dari pendidik yang bersangkutan. Sebagai tenaga profesional pendidik anak usia dini memiliki tugas utama untuk merencanakan pembelajaran, melaksanakan dan menilai hasil pembelajaran serta melakukan pembimbingan, pelatihan, pengasuhan dan perlindungan. 
BEduManageRs Journal

Borneo Educational Management and Research Journal, Vol.2, No.1, 2021

ISSN: 2747-0504

Pendidik anak usia dini era covid-19 berbeda secara tugas dan fungsi dengan pendidik PAUD pada situasi seperti biasanya yaitu pendidik anak usia dini yang sebelumnya kini harus dibantu oleh orang tua di rumah dalam menyiapkan bahan bermain, dalam mendampingi, dan mendokumentasikan kegiatan anak selama proses BDR. Hal ini dilaksanakan orang tua di rumah dalam melakukan stimulasi Pendidikan karakter sedangkan pendidik menyiapkan perencanaan pembelajaran yang akan dilakukan serta menilai hasil pembelajaran yang dikomunikasikan melalui grup whatapps satuan PAUD.

Adapaun aspek perkembangan yang diberi stimulasi oleh orang tua peserta didik di rumah sesuai dengan aspek perkembangan yang dikembangkan oleh pendidik PAUD di satuan pendidikan anak usia dini yaitu mulai dari aspek perkembangan kognitif, fisik motorik, bahasa, agama dan moral, seni dan sosial emosional. Selanjutnya dari ke enam aspek perkembangan tersebut dibagi menjadi dua komponen yaitu 1) Perkembangan prilaku diantaranya perkembangan nilai agama dan moral dan sosial emosional dan 2) Kemampuan dasar diantaranya perkembangan motorik, kognitif , bahasa dan seni seperti yang tampak pada gambar pengembagan enam aspek kemampuan anak usia dini di bawah ini:

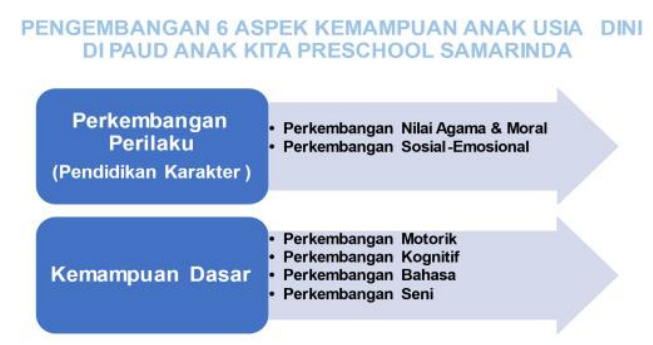

Gambar I

Pengembangan enam aspek kemampuan anak usia dini di PAUD Anak Kita Preschool
Aspek-aspek perkembangan tersebut di atas sesuai dengan ketentuan dalam peraturan menteri pendidikan dan kebudayaan nomor 137 tentang standar nasional pendidikan anak usia dini yang menyatakan bahwa standar tingkat pencapaian perkembangan anak sebagai kemampuan yang harus dicapai oleh anak usia dini pada enam aspek perkembangan yaitu nilai agama dan moral, fisik motorik, kognitif, bahasa, sosial emosional dan seni (Permendikbud, 2014).

Strategi pelaksanaan pembelajaran untuk anak usia dini yang dilakukan oleh pendidik yaitu : 1) Melakukan komunikasi dengan orang tua terlebih dahulu melalui pertemuan orang tua pendidik, 2) Penyampaian Rencana Pembelajaran oleh Pendidik kepada orang tua melalui WhatsApp Grup sekolah, 3) Pembelajaran langsung pendidik menyapa anak melalui media daring yaitu: video call, zoom Meeting, Home Visit, YouTube dan orang tua menjadi narasumber dikelas anak 4) Pengiriman dokumentasi Foto/ Video / Hasil Karya anak dari orang tua kepada Pendidik, 5) Pendidik melakukan penilaian dan menganalisis hasil karya anak, 6) Pendidik melaporkan perkembangan anak kepada orang tua. Adapun cara melakukan pembelajaran BDR di PAUD Anak kita Preschool terlihat pada bagan berikut ini:

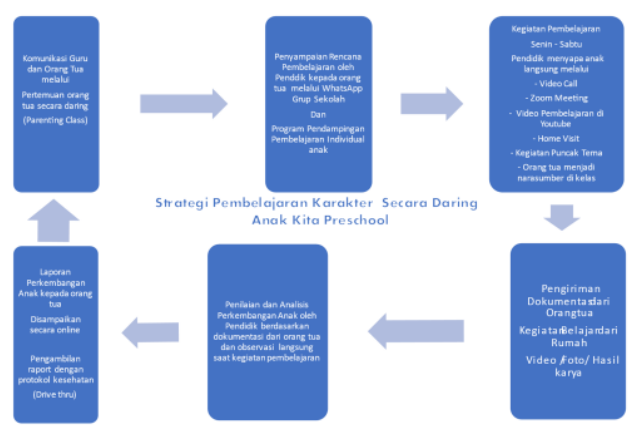

Gambar 2

Strategi pembelajaran karakter secara daring di PAUD Anak Kita Preschool

Jurnal BeduManagers, Vol.2, No.1, Juni 2021 
BEduManageRs Journal

Borneo Educational Management and Research Journal, Vol.2, No.1, 2021

ISSN: 2747-0504

Selanjutnya, pendidik PAUD berperan sebagai perencana kegiatan dan penilai hasil pembelajaran. Sementara untuk pelaksanaan pembelajaran dilakukan oleh orang tua di rumah masing-masing peserta didik tetap menggunakan prinsip bermain sambil belajar namun tetap diberikan penguatan oleh pendidik. Kegiatan bermain anak usia dini sebelumnya selalu bersama pendidik dan rekanrekan sejawatnya yaitu peserta didik lainnya di satuan PAUD karena adanya coronavirus disease atau covid-19 kegiatan bermain anak beralih dilakukan bersama dengan orang-orang terdekat anak yaitu orang tua dan anggota keluarga yang lain. Kegiatan bermain tersebut didukung oleh Mulyasa (2012) yang menyatakan bahwa permainan untuk anak usia dini sebagai metode pembelajaran terdapat beberapa jenis antara lain bermain sosial, bermain dengan benda dan bermain peran.

Pelaksanaan aktivitas bermain yang dilakukan di rumah untuk anak usia dini lebih dekat pada jenis metode bermain dengan benda yang ada di sekitar rumah mereka namun tetap berkaitan dengan tematik. Adapun jenis kegiatannya adalah bermain peran yaitu aktivitas bermain dengan memanfaatkan benda-benda di sekitar anak sebagai sarana bermain dan aktivitas bermain yang dimainkan anak berlakon sebagai orang lain, namun tetap mendapatkan pendampingan dari orang tua.

\section{KESIMPULAN}

Berdasarkan hasil penelitian yang telah dilaksanakan dapat disimpulkan bahwa ada perubahan kegiatan pembelajaran yang dilakukan saat sebelum dan saat sedang pandemic covid-19, Pertama : strategi pelaksanaan pembelajaran melalui kerjasama pendidik dan orang tua dengan berbagi tugas yaitu, Pendidik sebagai perencana dan penilaian hasil pembelajaran sedangkan untuk tugas pelaksana pembelajaran dilakukan oleh orangtua, sehingga orangtua menjadi mitra saat kegiatan pembelajaran dirumah, diantaranya tugas orang tua adalah menyiapkan alat dan bahan main yang dipinjamkan oleh sekolah dan ditambahkan dengan alat dan bahan main yang ada disekitar rumah, mendampingi anak, memberikan motivasi kepada anak dan mendokumentasikan kegiatan yang anak lakukan selanjutnya mengirimkan dokumentasi tersebut kepada wali kelas untuk dianalisis dan dilaporkan sebagai laporan perkembangan anak dilaksanakan Pendidik PAUD dibantu oleh orang tua dirumah, kedua : Nilainilai karakter ini dikembangkan ada dua belas antara lain: 1) Religius, 2) Jujur, 3) toleransi, 4)disiplin, 5) kerja keras, 6) kreatif, 7)mandiri, 8) rasa ingin tahu, 9)bersahabat/ komunikatif, 10) gemar membaca, 11) peduli lingkungan, dan 12) bertanggung Jawab. Ketiga: Strategi pendidik dalam menanamkan nilai-nilai karakter melalui kegiatan belajar dari rumah saat pandemic covid19 adalah melalui stimulasi, memberikan contoh, mendongeng dan pembiasaan yang baik dari pendidik dan orang tua serta dievaluasi berdasarkan enam aspek perkembangan anak usia dini.

\section{DAFTAR PUSTAKA}

Direktorat PAUD Kebijakan Kemendikbud Surat Edaran Nomor 4 tahun 2020. tentang Pelaksanaan Kebijakan Pendidikan dalam Masa Darurat Penyebaran Corona Virus Disease Covid-19 .Jakarta

Surat Edaran Menteri Pendidikan dan Kebudayaan Nomor 36962/MPK.A/HK/2020 Tentang Pembelajaran daring

Direktorat P2TK Dirjen PAUDNI Kemendikbud. 2012. Petunjuk teknis

Harini dan kawan kawan, Sri. 2003. Mendidik anak sejak sejak dini. Yogyakarta . Kreasi Wacana.

Kementrian Pendidikan Nasional Badan Kurikulum dan perbukuan .2012. Panduan

Jurnal BeduManagers, Vol.2, No.1, Juni 2021 
BEduManageRs Journal

Borneo Educational Management and Research Journal, Vol.2, No.1, 2021

ISSN: 2747-0504

pelaksanaan pendidikan karakter. Jakarta. Direktorat P2TK

Liana, Heppy. 2021. Pendidikan Karakter Anak Usia Dini, Surabaya. Mitra Mandiri Persada

Liana, Heppy. Rahardjo, Budi. Sjamsir, Hasbi. 2018, Implementasi pembelajaran karakter anak usia dini di PAUD Anak kita Preschool Samarinda.

http://103.8.79.252/index.php/pendasmahak am/article/view/222

Lickona, Thomas. 2012 . Character Matter Persoalan Karakter. Jakarta. Bumi Aksara

Miles, 1994. Matthew B and Huberman, Qualitative Data Analysis. An Expanded Soureebook . London. Sage Publication.

Musfiqon, H.M. 2012. Metodelogi Penelitian Pendidikan. Jakarta. Prestasi Pustaka Publisher.

Moleong,Lexy. 1997. Metodologi Penelitian kualitatif. Bandung .Rajawali Pers.

Roopnarine,Jaipaul L. James E. Johnson. 2011. Pendidikan Anak Usia Dini dalam berbagai pendekatan, edisi kelima . Jakarta. kencana .

Salahudin, Anas. Alkrienciechie, Irwanto, 2013. Pendidikan karakter pendidikan berbasis agama dan budaya bangsa. Bandung. Pustaka Setia.

Samani, Muchlas. Hariyanto. 2012. Konsep dan Model Pendidikan Karakter. Bandung . Remaja Rosdakarya.

Sjamsir, Hasbi. 2018. The Influence of TPR, GTM Methods and Linguistics Intelligence toward the Learning Outcomes in English DAP Based. ( A case study at Elementary School Samarinda). Journal of English Literature and Language Review. Vol.4, Issue 4, pp:58-61.

https://ideas.repec.org/a/arp/ellrar/2018p58$\underline{61 . h t m l}$
Sujiono, Yuliani Nurani. 2013. Konsep dasar Pendidikan Anak Usia Dini Jakarta. indek

Sugiyono, 2005. Memahami penelitian kualitatif. Bandung .Alfabeta.

Suyadi. 2013. Strategi Pembelajaran Pendidikan Karakter. Bandung. remaja rosdakarya.

Taylor, Steve J dan R. Bogdan. 1984. Introduction to Quality Research Methods New York . Wiley.

Patton, Michael Quinn. 1987. Qualitative Evaluation and Research Methods. New Delhi . Sage Publication.

Pendidikan Anak Usia Dini (online). http.//id.wikipedia.org/wiki/Pendidikan, diakses tanggal 27 Mei 2006

Yin, Robert K. 2013. Case Study Research. Design and Methods terjemahan M. Djauzi Mudzakir . Jakarta . Grafindo Persada. 